\title{
What is the burden of osteomyelitis in Germany? An analysis of inpatient data from 2008 through 2018
}

\author{
Nike Walter ${ }^{1,2}$, Susanne Baertl ${ }^{1}$, Volker Alt ${ }^{1}$ and Markus Rupp ${ }^{1 *}$
}

\begin{abstract}
Background: The epidemiology of osteomyelitis in Germany is unknown, which makes it difficult to estimate future demands. Therefore, we aimed to analyse how the numbers of cases have developed over the last decade as a function of osteomyelitis subtype, age group, gender, and anatomical localization.

Methods: Osteomyelitis rates were quantified based on annual ICD-10 diagnosis codes from German medical institutions between 2008 through 2018, provided by the Federal Statistical Office of Germany (Destatis).

Results: Overall osteomyelitis prevalence increased by $10.44 \%$ from 15.5 to 16.7 cases per 100,000 inhabitants between 2008 through 2018. Out of 11,340 cases in 2018, 47.6\% were diagnosed as chronic, 33.2\% as acute and $19.2 \%$ as unspecified osteomyelitis. Men were often affected than women with $63.4 \%$ of all cases compared to $36.6 \%$. The largest proportion of patients comprised the age group 60-69 years (22.1\%), followed by 70-79 years (21.7\%). A trend towards more osteomyelitis diagnoses in older patients was observed. Lower extremities were most frequently infected with $73.8 \%$ of all cases in 2018 (+ 10.8\% change).
\end{abstract}

Conclusions: Osteomyelitis remains a serious problem for orthopedic and trauma surgery. Prevention methods and interdisciplinary approaches are strongly required.

Keywords: Osteomyelitis, Bone infection, Epidemiology, Nationwide burden, Musculoskeletal disorder

\section{Background}

Osteomyelitis has accompanied mankind from its very beginning and still remains a difficult to manage challenge in orthopaedic and trauma surgery [1]. Osteomyelitis can occur to a variety of reasons. Hematogenous infection is possible as well as direct inoculation of bacteria to bone, which occurs in open fractures, after surgery or skin breakdown secondary to vascular insufficiency or peripheral neuropathy [2]. Several classifications for osteomyelitis exist such as the one introduced by Waldvogel and colleagues or George Cierny and John Mader. The

\footnotetext{
*Correspondence: markus.rupp@ukr.de

'Department for Trauma Surgery, University Medical Center Regensburg, Franz-Josef-Strauß-Allee 11, 93053 Regensburg, Germany

Full list of author information is available at the end of the article
}

former includes a temporal distinction between acute and chronic, which is important for the treatment strategy [2, 3]. In acute osteomyelitis, defined by symptoms less than 2 weeks, empirical antibiotic long-term therapy is feasible since establishment of a mature biofilm might not have taken place, which is the hallmark of chronic osteomyelitis. Once formation of biofilm is accomplished, susceptibility to antibiotic therapy is significantly reduced and eradication of infection without surgical treatment is not possible [3].

While there was no curative therapy until modern times, advances in modern medicine have led to the fact that at least osteomyelitis is no longer associated with an almost inevitable death. Milestones for a curative treatment are the development of surgical treatment concepts

C C The Author(s). 2021 Open Access This article is licensed under a Creative Commons Attribution 4.0 International License, which permits use, sharing, adaptation, distribution and reproduction in any medium or format, as long as you give appropriate credit to the original author(s) and the source, provide a link to the Creative Commons licence, and indicate if changes were made. The images or other third party material in this article are included in the article's Creative Commons licence, unless indicated otherwise in a credit line to the material. If material is not included in the article's Creative Commons licence and your intended use is not permitted by statutory regulation or exceeds the permitted use, you will need to obtain permission directly from the copyright holder. To view a copy of this licence, visit http://creativecommons.org/licenses/by/4.0/ The Creative Commons Public Domain Dedication waiver (http://creativecommons.org/publicdomain/zero/1.0/) applies to the data made available in this article, unless otherwise stated in a credit line to the data. 
which focus on infect eradication followed by bone defect reconstruction. The discovery of penicillin and further development of an array of different antibiotics, the use of local antibiotic carriers as well as surgical procedures such as bone transfer introduced by Ilizarov, Masquelet's membrane induced technique or free flap surgery invented by Harry J Buncke contributed to the progress in orthopaedic and trauma surgery [4-7]. Although joint replacement procedures and surgical fracture treatment with internal fixation devices have become an integral part of modern medicine enhancing patients' quality of life, they represent an additional risk of bone and joint infection. For instance, rates of developing a posttraumatic infection are reported to be around $1-2 \%$ for closed fractures ranging up to exceeding 30\% for Gustilo-Anderson type III open tibia fractures despite prevention strategies [8-11]. Depending on injury severity, success rates only vary between 70 and $90 \%$ with a recurrence of the disease in $6-9 \%$ of the patients [12-14]. Healthcare costs of fracture-related infections were estimated to be approximately 6.5 times higher than in non-infected cases [15]. As incidences of long bone fractures increase, projected numbers of infection complications are expected to rise as well [16]. Additionally, the global prevalence of diabetes is projected to increase up to 7079 individuals per 100,000 by 2030 [17], hence also heightening the risk of osteomyelitis.

To estimate future demands for this potentially coming challenge and to foresee developments which could be influenced by adaption of prevention and therapeutic measures, analysis of trends in osteomyelitis rates are required. However, no analysis of the epidemiology of osteomyelitis for European countries is available.

We have therefore aimed to answer the following questions: (1) How have the numbers of cases developed over the last decade as a function of osteomyelitis subtype and localization? (2) How does age and gender influence the numbers in the observation period?

\section{Methods}

Data consisting of annual ICD-10 diagnosis codes, which were implemented in Germany in January 2000, from German medical institutions between 2008 to 2018 was provided by the Federal Statistical Office of Germany (Destatis). The dataset included only patients who received inpatient treatment. The ICD-10 code "M86.-" was used to identify patients aged 20 years or older diagnosed with osteomyelitis. A detailed breakdown of these data by age group, gender, type of osteomyelitis and anatomical localization was performed. In particular, for composing the subgroup "acute osteomyelitis, the ICD-10 codes "M86.0, M86.1, M86.2" were used, whereas chronic osteomyelitis was determined by the codes "M86.3, M86.4, M86.5, M86.6" and unspecified osteomyelitis by "M86.8, M86.9". Localization was retrieved by using the codes "- 1 , shoulder", "- 2 , humerus", " -3 , radius and ulna", and "- 4 , hand" to compile the upper extremity subgroup and "-5, femur", "-6, tibia and fibula" and " -7 , ankle and foot" for the lower extremity subgroup, respectively. Prevalence rates were calculated based on Germany's historical population aged 20 years or older provided by Destatis [18]. Here, the number of inhabitants in each of the 16 German federal states was considered by year of birth for each year of the period 2008 to 2018. The deadline of each year was December 31. Data were analyzed using the statistical software SPSS Version 26.0 (IBM, SPSS Inc. Armonk, NY, USA).

\section{Results}

In 2018 , a total number of 11,340 osteomyelitis cases in Germany was reported. In comparison to 10,268 cases in 2008 , the overall prevalence increased by $10.44 \%$ from 15.5 cases per 100,000 inhabitants to 16.7 cases per 100 , 000 inhabitants. Between 2008 through 2012 total numbers decreased and subsequently rose again with a maximum of cases in the year 2016. (Table 1). The largest proportion of osteomyelitis cases in 2018 comprised chronic cases (47.6\%), followed by $33.2 \%$ acute cases and $19.2 \%$ unspecified cases. The total number of cases diagnosed with acute osteomyelitis increased by $61.8 \%$ from 2327 to 3765 between 2008 and 2018. An increasing trend could also be observed regarding chronic osteomyelitis cases, which heightened by $8.4 \%$ from 4984 to 5402 cases in total between 2008 and 2018, whereas osteomyelitis cases classified as unspecified decreased by 26.5\% from 2957 to 2173 patients (Table 2).

Overall, men were more often affected than women, whereby the proportion of male cases increased from 61.4 to $63.4 \%$ and female cases decreased from 38.6 to $36.6 \%$ accordingly (Fig. 1, Table 3). Patients aged 60-69

Table 1 Historic development of population and osteomyelitis prevalence from 2008 to 2018

\begin{tabular}{lllll}
\hline Year & $\begin{array}{l}\text { Total } \\
\text { numbers }\end{array}$ & $\begin{array}{l}\text { Relative to } \\
\text { 2008 [\%] }\end{array}$ & $\begin{array}{l}\text { German population } \\
\text { 20 years or older }\end{array}$ & $\begin{array}{l}\text { Prevalence } \\
\text { per 100,000 } \\
\text { inhabitants }\end{array}$ \\
\hline 2008 & 10,268 & & $66,346,045$ & 15.5 \\
2009 & 9932 & -3.27 & $66,400,066$ & 15.0 \\
2010 & 9893 & -3.65 & $66,549,975$ & 14.9 \\
2011 & 10,053 & -2.09 & $65,398,514$ & 15.4 \\
2012 & 10,107 & -1.57 & $65,665,069$ & 15.4 \\
2013 & 10,452 & +1.79 & $65,943,867$ & 15.8 \\
2014 & 10,351 & +0.81 & $66,677,665$ & 15.5 \\
2015 & 10,860 & +5.77 & $67,097,676$ & 16.2 \\
2016 & 11,480 & +11.8 & $67,440,230$ & 17.0 \\
2017 & 11,331 & +10.35 & $67,540,025$ & 16.8 \\
2018 & 11,340 & +10.44 & $67,724,921$ & 16.7 \\
\hline
\end{tabular}


Table 2 Historic development of osteomyelitis subtypes from 2008 to 2018

\begin{tabular}{llll}
\hline Year & $\begin{array}{l}\text { Acute osteomyelitis } \\
\text { cases (percentage) }\end{array}$ & $\begin{array}{l}\text { Chronic osteomyelitis } \\
\text { cases (percentage) }\end{array}$ & $\begin{array}{l}\text { Unspecified osteomyelitis } \\
\text { cases (percentage) }\end{array}$ \\
\hline 2008 & $2327(22.7)$ & $4984(48.5)$ & $2957(28.8)$ \\
2009 & $2292(23.1)$ & $4748(47.8)$ & $2892(29.1)$ \\
2010 & $2306(23.3)$ & $4848(49.0)$ & $2739(27.7)$ \\
2011 & $2444(24.3)$ & $4997(49.7)$ & $2612(26.0)$ \\
2012 & $2480(24.5)$ & $4914(48.6)$ & $2713(26.8)$ \\
2013 & $2644(25.3)$ & $4983(47.7)$ & $2825(27.0)$ \\
2014 & $2636(25.5)$ & $4988(48.2)$ & $2727(26.3)$ \\
2015 & $2799(25.8)$ & $5347(49.2)$ & $2714(25.0)$ \\
2016 & $3414(29.7)$ & $5720(49.8)$ & $2346(20.4)$ \\
2017 & $3621(32.0)$ & $5446(48.1)$ & $2264(20.0)$ \\
2018 & $3765(33.2)$ & $5402(47.6)$ & $2173(19.2)$ \\
\hline
\end{tabular}

a

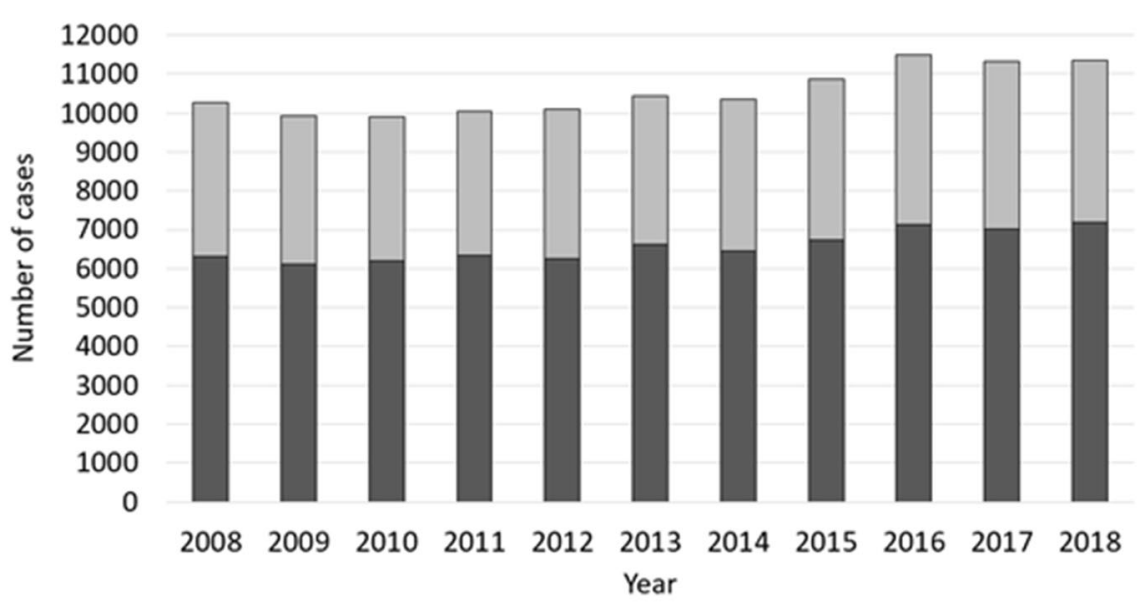

$\square$ Male $\square$ Female

b

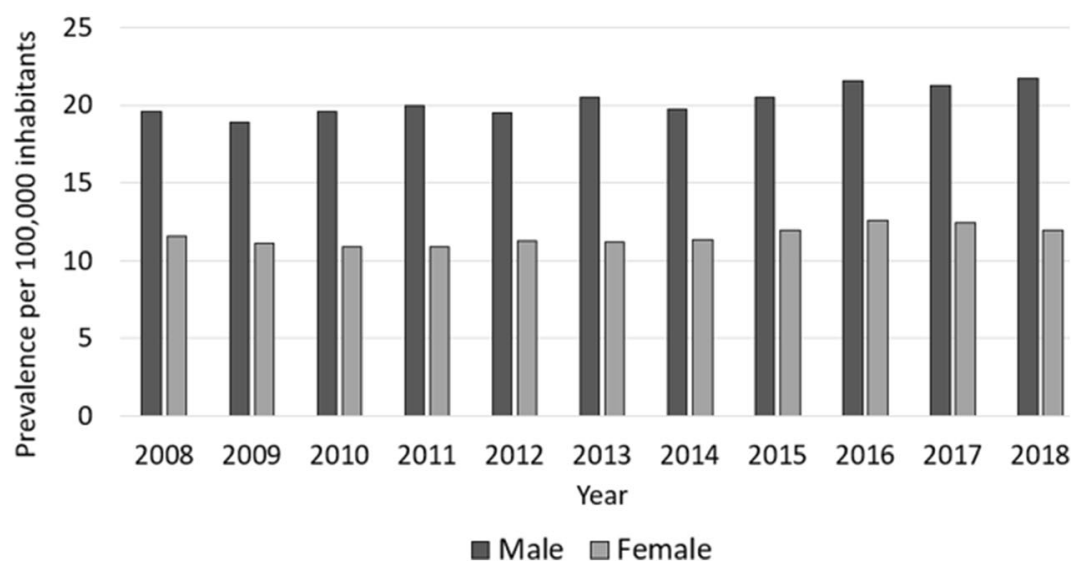

Fig. 1 Development of osteomyelitis diagnoses as a factor of gender. a Shows the amount of total cases per year. Male cases are shown in dark grey, female cases in light grey. b The prevalence per 100,000 male inhabitants is shown in dark grey, prevalence per 100,000 female inhabitants is illustrated in light grey 


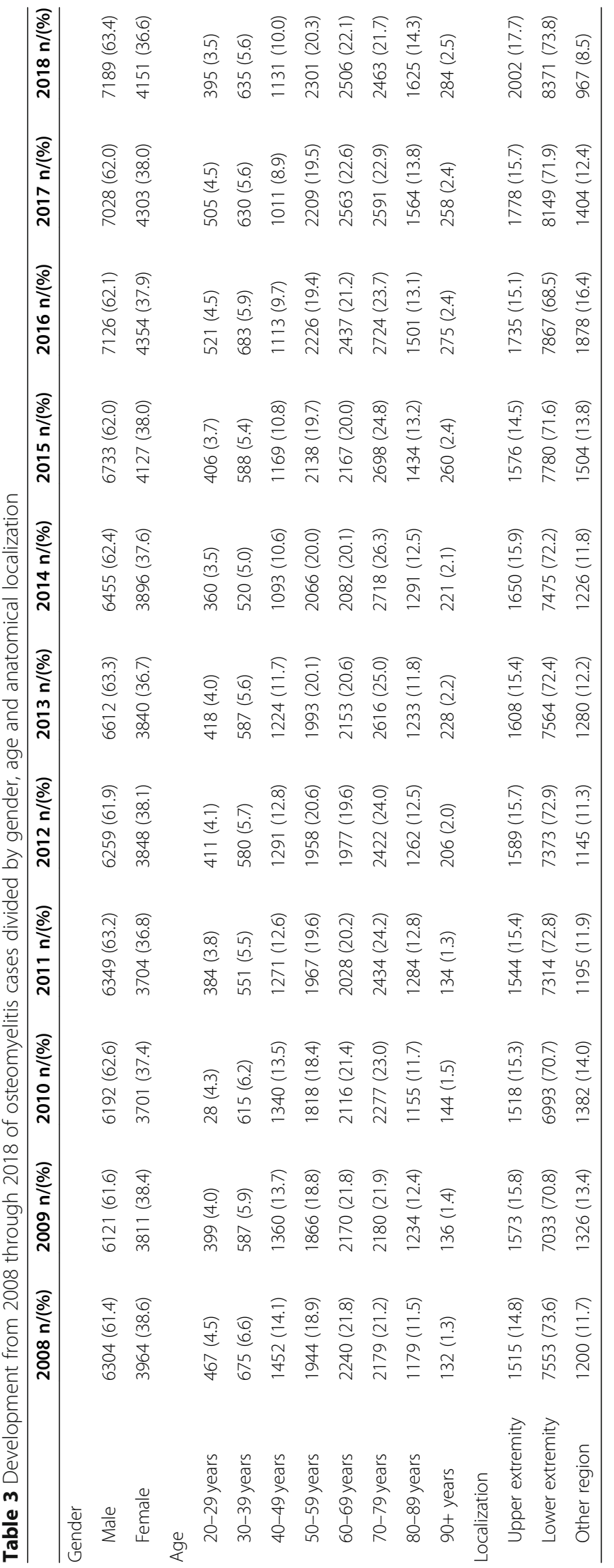


years comprised the largest cohort with $22.1 \%$, followed by patients aged $70-79$ years $(21.7 \%)$ and patients aged $50-59$ years $(20.3 \%)$. Relative to the year 2008 , a trend towards more osteomyelitis diagnoses in older patients can be observed. The largest increase was found in the population aged 90 years or older $(+115.2 \%$ change $)$. In the increment $80-89$ years $37.8 \%$ more cases were registered and $13.0 \%$ more patients in the age between 70 and 79 years were affected. Also, the prevalence heightened in patients aged $60-69$ years $(+11.9 \%$ change $)$ and in patients aged $50-59$ years (+ $18.4 \%$ change). Accordingly, less patients aged $40-49$ years were diagnosed with osteomyelitis $(-22.1 \%$ change) and numbers decreased in the age group $30-39$ years $(-5.9 \%$ change) as well as $20-29$ years $(-15.4 \%$ change) (Fig. 2 , Table 3$)$. The most frequently infected region was the lower extremity with $73.8 \%$ of all cases in 2018 , whereby numbers rose by 10.8\% from 7553 cases in 2008 to 8371 cases in 2018 .
Osteomyelitis occurred in $17.7 \%$ of all cases at the upper extremity, with an increase of $32.14 \%$ from 1515 cases in 2008 to 2002 cases in 2018. Other regions were involved in $8.5 \%$ of all cases, with decreasing prevalence of $19.4 \%$ from 1200 cases in 2008 to 967 cases in 2018 (Fig. 3, Fig. 4, Table 3).

\section{Discussion}

In this population-based study trends in the epidemiology of osteomyelitis were described and prevalence was analyzed as a function of osteomyelitis subtype, anatomical localization, gender, and age group. Some literature provides insights regarding selected subgroups or subtypes of osteomyelitis, such as pediatric patients [19, 20] or vertebral osteomyelitis [21]. Additionally, the epidemiology of osteomyelitis has been analyzed based on a survey of residents of Olmsted County, Minnesota, United States, reporting 760 cases [22]. However, there

a

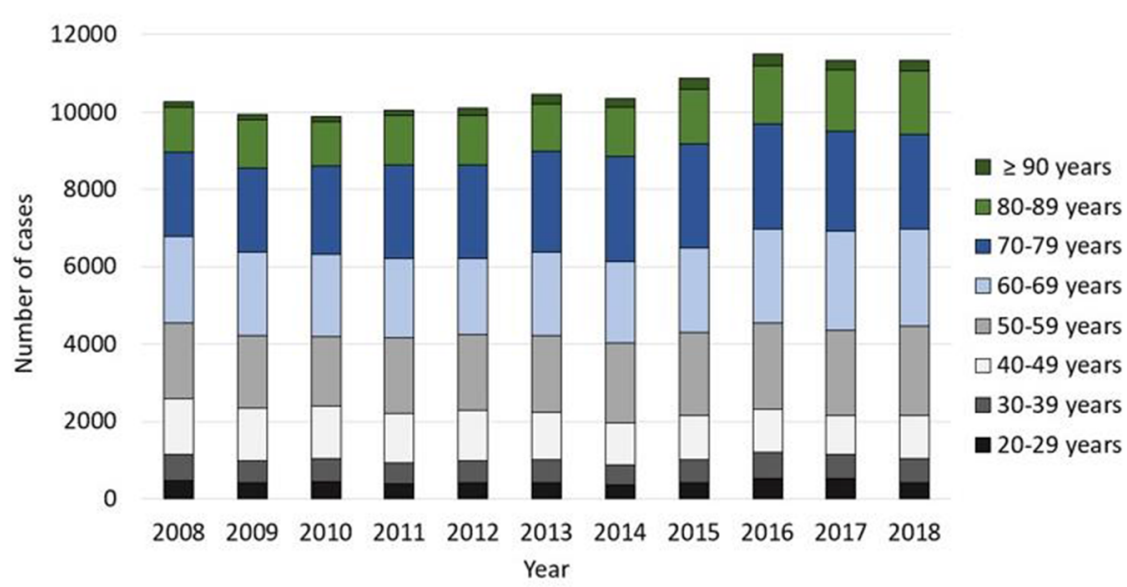

b

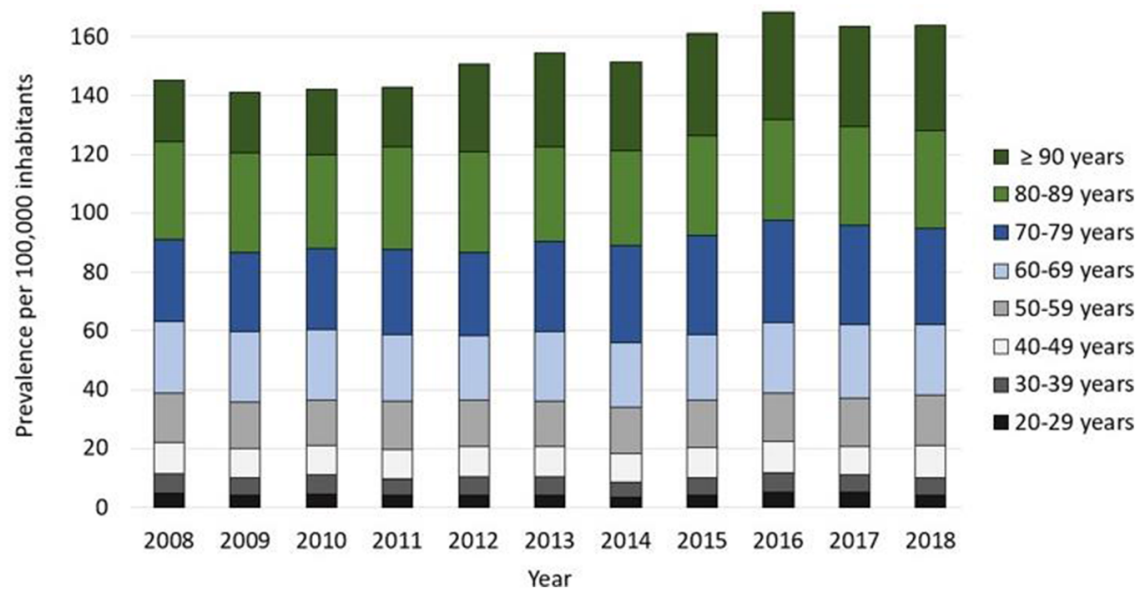

Fig. 2 Development of osteomyelitis numbers as a factor of age groups in 10-year increments. a Total number of osteomyelitis diagnoses, (b) age standardized prevalence per 100,000 inhabitants 


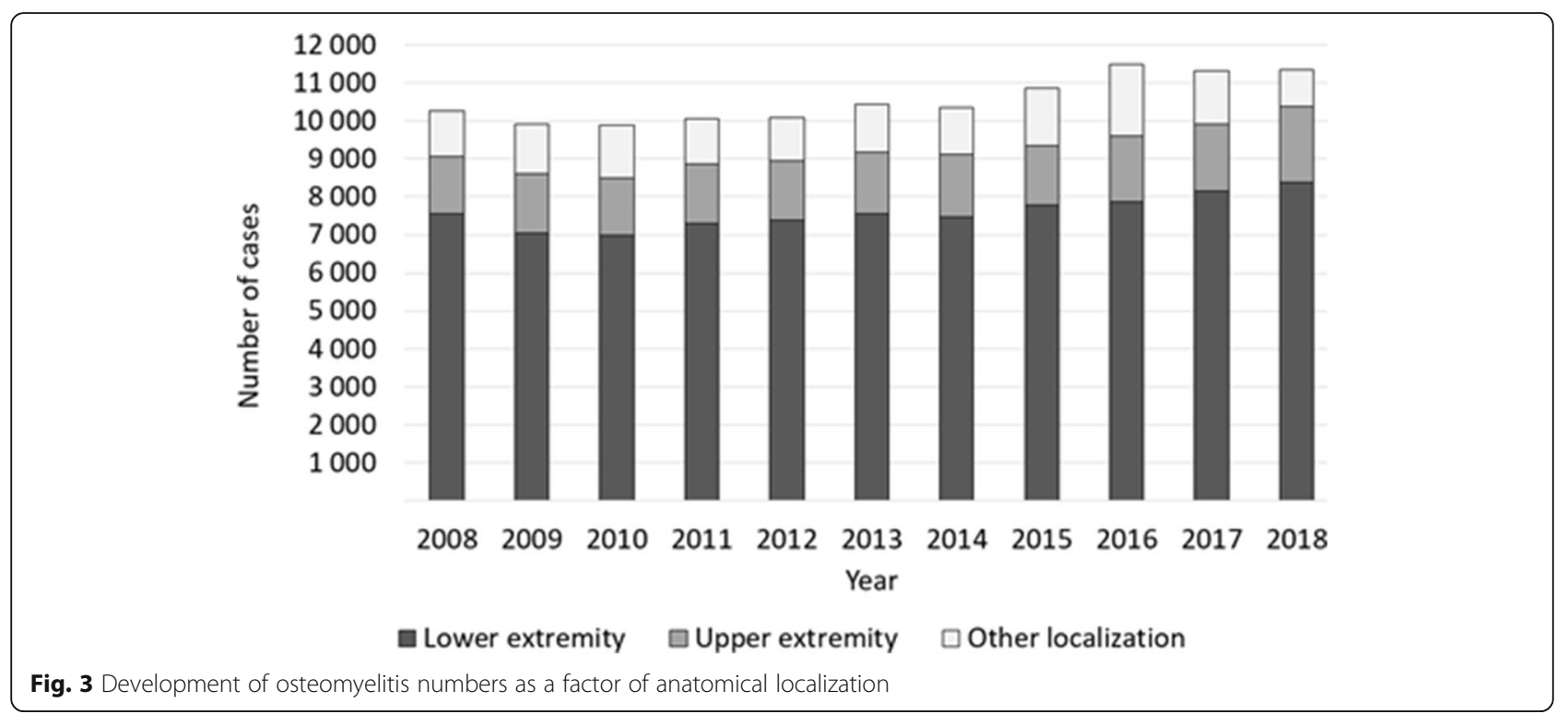

is a lack of data estimating the prevalence of osteomyelitis for European countries. This study, to the best of our knowledge, is the first one describing the nationwide burden of osteomyelitis.

It was demonstrated that the number of cases increased by $10.44 \%$ over the last decade up to 16.7 per 100,000 inhabitants in 2018. In the light of a recent study calculating annual numbers of revision total knee arthroplasty procedures associated with periprosthetic joint infection (PJI) as 30.8 per 100,000 German inhabitants in 2018, forecasting an increase of almost $90 \%$ in 2050 [23], the dynamic in total osteomyelitis numbers seem surprisingly low. Here, the importance of delimitation between osteomyelitis and PJI becomes evident. Whereas the lines between the two diagnoses often appear to be blurred in literature [24-26], strictly applying the definition criteria of the European Bone and Joint Infection Society (EBIIS) [27] excludes PJI from the category 'bone infection'. Further, PJI is distinctly coded according to the ICD-10 as "T84.5, infection and inflammatory reaction by a joint endoprosthesis" and therefore, not included in our analysis. Also, the prevalence rates in Germany were lower in comparison to 24.4 incident cases of osteomyelitis per 100,000 person-years estimated for the U. S [22], which might be

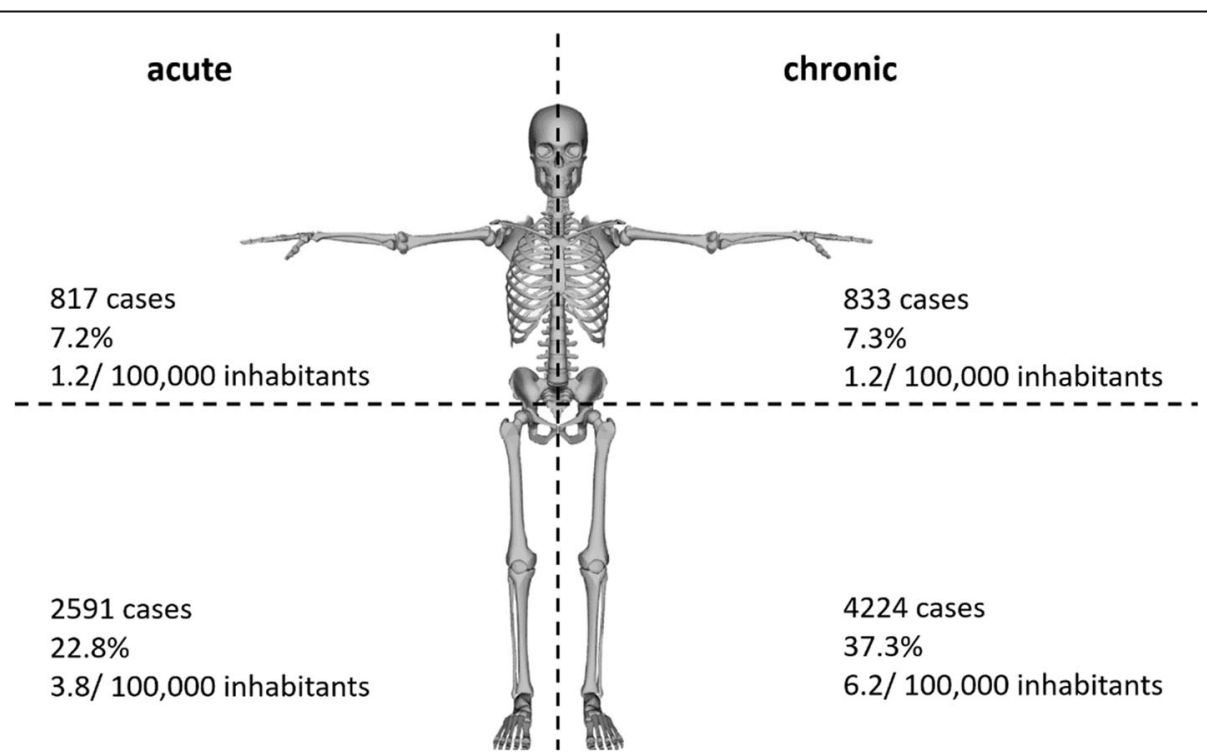

Fig. 4 Acute and chronic osteomyelitis cases for the upper and lower extremity, respectively 
explainable by differences in methodology. For instance, we did not consider vertebral osteomyelitis as spondylodiscitis is coded separately.

Our analysis also revealed that men were often affected than women, which is in accordance with findings by Kremers and colleagues reporting significantly lower incidences of 16.7 cases per 100,000 person-years for women compared to $27.7 / 100,000$ for men [22]. Whereas underlying mechanisms are not fully understood yet, research increasingly addresses the importance of sex differences in immune response [28, 29]. The observed trend towards more osteomyelitis diagnosis in older patients possibly reflects demographic changes such as population decline and aging, which challenge the healthcare system not only in Germany. Further, higher numbers of chronic cases compared to acute cases were determined, whereas the prevalence of acute osteomyelitis rose by $61.8 \%$. This finding may be attributable to recent advances in prevention strategies, early diagnosis of low-grade infections or awareness to discriminate acute and chronic bone infections [11, 30, 31]. However, potential biases in the distinction between acute and chronic osteomyelitis might influence these numbers as different definitions exits in the literature [32].

Our study is limited by the fact, that, although ICD-10 codes were available, it was not possible to differentiate possible driving comorbid factors, such as diabetes mellitus, peripheral vascular disease, trauma or the implantation of medical devices. Additionally, the analysed dataset did not include information regarding treatment procedure. Further, no statement regarding the distribution of pathogens causing the infection can be made. Also, we assumed correct diagnosing based on published criteria [31], however, a possible upcoding cannot be excluded.

\section{Conclusions}

Osteomyelitis remains a serious problem for orthopedic and trauma surgery, also for countries comparable with Germany. In light of a strong increase especially in elderly patients, prevention strategies, improved treatment strategies and an interdisciplinary treatment approach are required.

\section{Acknowledgements}

We thank the Federal Statistical Office of Germany (Destatis) for their support of this work.

\section{Authors' contributions}

All authors conceptualized the work, MR acquired the data, NW and SB analysed the data, all authors interpreted the data. NW and MR drafted the manuscript. All authors revised it critically for important intellectual content and approved the version to be published.

\section{Funding}

No specific funding was received for this study. Open Access funding enabled and organized by Projekt DEAL.

\section{Availability of data and materials}

The datasets generated and analysed during the currents study are available from the corresponding author on reasonable request.

\section{Declarations}

\section{Ethics approval}

This is a purely observational study. The Research Ethics Committee of the University Hospital Regensburg has confirmed that no approval is required. The study was performed in accordance with the ethical standards in the 1964 Declaration of Helsinki. No administrative permission was required to access the analysed dataset. The data was anonymised before it use.

Consent for publication

Not applicable.

\section{Competing interests}

The authors declare that they have no competing interests.

\section{Author details}

${ }^{1}$ Department for Trauma Surgery, University Medical Center Regensburg, Franz-Josef-Strauß-Allee 11, 93053 Regensburg, Germany. ${ }^{2}$ Department for Psychosomatic Medicine, University Medical Center Regensburg,

Franz-Josef-Strauß-Allee 11, 93053 Regensburg, Germany.

Received: 16 March 2021 Accepted: 2 June 2021

Published online: 10 June 2021

\section{References}

1. Klenerman L. A history of osteomyelitis from the journal of bone and joint surgery: 1948 to 2006. J Bone Joint Surg (Br). 2007;89(5):667-70. https://doi. org/10.1302/0301-620X.89B5.19170.

2. Waldvogel FA, Medoff G, Swartz MN. Osteomyelitis: a review of clinical features, therapeutic considerations and unusual aspects. N Engl J Med. 1970;282(4):198-206. https://doi.org/10.1056/NEJM197001222820406.

3. Cierny G III, Mader JT, Penninck JJ. The classic: a clinical staging system for adult osteomyelitis. Clin Orthop Relat Res. 2003;414:7-24. https://doi.org/1 0.1097/01.blo.0000088564.81746.62.

4. Buncke HJ. Microsurgery--retrospective. Clin Plast Surg. 1986;13(2):315-8. https://doi.org/10.1016/S0094-1298(20)31598-4.

5. Lowenberg DW, Feibel RJ, Louie KW, Eshima I. Combined muscle flap and Ilizarov reconstruction for bone and soft tissue defects. Clin Orthop Relat Res. 1996:332:37-51. https://doi.org/10.1097/00003086-199611000-00007.

6. Morelli I, Drago L, George DA, Gallazzi E, Scarponi S, Romanò CL. Masquelet technique: myth or reality? A systematic review and meta-analysis. Injury. 2016;47:68-76. https://doi.org/10.1016/S0020-1383(16)30842-7.

7. Cortés-Penfield NW, Kulkarni PA. The history of antibiotic treatment of osteomyelitis. Open Forum Infect Dis. 2019;6(5):ofz181. https://doi.org/10.1 093/ofid/ofz181.

8. Trampuz A, Zimmerli W. Diagnosis and treatment of infections associated with fracture fixation devices. Injury. 2006;37:59-66. https://doi.org/10.1016/j. injury.2006.04.010.

9. Ktistakis I, Giannoudi M, Giannoudis PV. Infection rates after open tibial fractures: are they decreasing? Injury. 2014;45(7):1025-7. https://doi.org/10.1 016/j.injury.2014.03.022.

10. Metsemakers WJ, Onsea J, Neutjens E, Steffens E, Schuermans A, McNally M, et al. Prevention of fracture-related infection: a multidisciplinary care package. Int Orthop. 2017;41(12):2457-69. https://doi.org/10.1007/s00264-01 7-3607-y.

11. Rupp M, Popp D, Alt V. Prevention of infection in open fractures: where are the pendulums now? Injury. 2020;51(Suppl 2):S57-63. https://doi.org/10.101 6/j.injury.2019.10.074

12. Bezstarosti H, Van Lieshout EMM, Voskamp LW, Kortram K, Obremskey W, McNally MA, et al. Insights into treatment and outcome of fracture-related infection: a systematic literature review. Arch Orthop Trauma Surg. 2019; 139(1):61-72. https://doi.org/10.1007/s00402-018-3048-0. 
13. Bose D, Kugan R, Stubbs D, McNally M. Management of infected nonunion of the long bones by a multidisciplinary team. Bone Joint J. 2015;97-B(6): 814-7. https://doi.org/10.1302/0301-620X.97B6.33276.

14. Metsemakers WJ, Kuehl R, Moriarty TF, Richards RG, Verhofstad MHJ Borens $\mathrm{O}$, et al. Infection after fracture fixation: current surgical and microbiological concepts. Injury. 2018;49(3):511-22. https://doi.org/10.101 6/j.injury.2016.09.019.

15. Metsemakers WJ, Smeets B, Nijs S, Hoekstra H. Infection after fracture fixation of the tibia: analysis of healthcare utilization and related costs. Injury. 2017:48(6):1204-121. https://doi.org/10.1016/j.injury.2017.03.030

16. Amin S, Achenbach SJ, Atkinson EJ, Khosla S, Melton $\sqcup$ J 3rd. Trends in fracture incidence: a population-based study over 20 years. J Bone Miner Res. 2014;9(3):581-9. https://doi.org/10.1002/jbmr.2072.

17. Khan MAB, Hashim MJ, King JK, Govender RD, Mustafa H, Al KJ. Epidemiology of type 2 diabetes - global burden of disease and forecasted trends. J Epidemiol Glob Health. 2020;10(1):107-11. https://doi.org/10.2991/ jegh.k.191028.001.

18. Statistisches Bundesamt (Destatis), http://www-genesis.destatis.de/genesis/ online. Accessed 25 Nov 2020.

19. Riise ØR, Kirkhus E, Handeland KS, Flatø B, Reiseter T, Cvancarova M, et al. Childhood osteomyelitis-incidence and differentiation from other acute onset musculoskeletal features in a population-based study. BMC Pediatr. 2008;8(1):45. https://doi.org/10.1186/1471-2431-8-45.

20. Okubo Y, Nochioka K, Testa M. Nationwide survey of pediatric acute osteomyelitis in the USA. J Pediatr Orthop B. 2017;26(6):501-6. https://doi. org/10.1097/BPB.0000000000000441.

21. Issa K, Diebo BG, Faloon M, Naziri Q, Pourtaheri S, Paulino CB, et al. The epidemiology of vertebral osteomyelitis in the United States from 1998 to 2013. Clin Spine Surg. 2018;31(2):102-8. https://doi.org/10.1097/BSD. 0000000000000597.

22. Kremers HM, Nwojo ME, Ransom JE, Wood-Wentz CM, Melton $\sqcup$ 3rd, Huddleston PM 3rd. Trends in the epidemiology of osteomyelitis: a population-based study, 1969 to 2009. J Bone Joint Surg. 2015;97(10):83745. https://doi.org/10.2106/JBJS.N.01350

23. Klug A, Gramlich Y, Rudert M, Drees P, Hoffmann R, Weißenberger M, et al. The projected volume of primary and revision total knee arthroplasty will place an immense burden on future health care systems over the next 30 years. Knee Surg Sports Traumatol Arthrosc. 2020:1-12. https://doi.org/10.1 007/s00167-020-06154-7.

24. Birt MC, Anderson DW, Bruce Toby E, Wang J. Osteomyelitis: recent advances in pathophysiology and therapeutic strategies. J Orthop. 2016; 14(1):45-52. https://doi.org/10.1016/j.jor.2016.10.004.

25. Masters EA, Trombetta RP, de Mesy Bentley KL, et al. Evolving concepts in bone infection: redefining "biofilm", "acute vs. chronic osteomyelitis", "the immune proteome" and "local antibiotic therapy". Bone Res. 2019;7:20. https://doi.org/10.1038/s41413-019-0061-z.

26. Seebach E, Kubatzky KF. Chronic implant-related bone infections-can immune modulation be a therapeutic strategy? Front Immunol. 2019;10: 1724. https://doi.org/10.3389/fimmu.2019.01724.

27. Zimmerli W, Trampuz A, Ochsner PE. Prosthetic-joint infections. N Engl J Med. 2004;351(16):1645-54. https://doi.org/10.1056/NEJMra040181.

28. Klein SL, Flanagan KL. Sex differences in immune responses. Nat Rev Immunol. 2016;16(10):626-38. https://doi.org/10.1038/nri.2016.90.

29. Ingersoll MA. Sex differences shape the response to infectious diseases. PLoS Pathog. 2017;13(12):e1006688. https://doi.org/10.1371/journal.ppat.1 006688

30. Panteli M, Giannoudis PV. Chronic osteomyelitis: what the surgeon needs to know. EFORT Open Rev. 2017;1(5):128-35. https://doi.org/10.1302/20585241.1.000017.

31. Glaudemans AWJM, Jutte PC, Cataldo MA, Cassar-Pullicino V, Gheysens O, Borens $\mathrm{O}$, et al. Consensus document for the diagnosis of peripheral bone infection in adults: a joint paper by the EANM, EBJIS, and ESR (with ESCMID endorsement). Eur J Nucl Med Mol Imaging. 2019;46(4):957-70. https://doi. org/10.1007/s00259-019-4262-x.

32. Hotchen AJ, McNally MA, Sendi P. The classification of long bone osteomyelitis: a systemic review of the literature. J Bone Jt Infect. 2017;2(4): 167-74. https://doi.org/10.7150/jbji.21050.

\section{Publisher's Note}

Springer Nature remains neutral with regard to jurisdictional claims in published maps and institutional affiliations.

\section{Ready to submit your research? Choose BMC and benefit from:}

- fast, convenient online submission

- thorough peer review by experienced researchers in your field

- rapid publication on acceptance

- support for research data, including large and complex data types

- gold Open Access which fosters wider collaboration and increased citations

- maximum visibility for your research: over $100 \mathrm{M}$ website views per year

At $\mathrm{BMC}$, research is always in progress.

Learn more biomedcentral.com/submissions 